\title{
DESIGN OF SOLUTIONIZING HEAT TREATMENTS FOR AN EXPERIMENTAL SINGLE CRYSTAL SUPERALLOY
}

\author{
S.R. Hegde ${ }^{1}$, R.M. Kearsey ${ }^{2}$, J. Beddoes ${ }^{1}$ \\ ${ }^{1}$ Department of Mechanical and Aerospace Engineering, Carleton University, Ottawa, ON, Canada \\ ${ }^{2}$ Institute for Aerospace Research, SMPL-National Research Council, Ottawa, ON, Canada
}

Key words: Single Crystal; Segregation; Heat Treatment; Incipient Melting; EPMA

\begin{abstract}
The heat treatment response between $1170^{\circ} \mathrm{C}$ and $1320^{\circ} \mathrm{C}$ of an experimental single crystal $\mathrm{Ni}$ base superalloy is presented. The temperature range for solutionizing the alloy is determined by combinations of holding time and temperature. The effects of long isothermal holding within and beyond this solutioning temperature range are studied. Heat treatment steps below the $\gamma^{\prime}$-solvus temperature stabilize the eutectic phase, while steps above the solvus temperature improve the homogenization and reduce eutectic phase fraction. However, prolonged holding above the solvus temperature indicates up-hill diffusion at the eutectic region leading to incipient melting. A new solutioning heat treatment approach with continuous heating between solvus and solidus is proposed
\end{abstract}

\section{Introduction}

As cast microstructures of Ni-base superalloys are highly heterogeneous due to coring during solidification [1,2]. To increase the high temperature capabilities, modern single crystal (SX) superalloys are alloyed with the refractory elements, W, Ta, and Re [3]. As a consequence, the microsegregation of these alloys is being more pronounced leading to higher eutectic fractions [4] and chemical instabilities [5]. Hence, heat treatment of modern SX alloys is becoming an increasingly challenging, time consuming and expensive process [6]. For the most part, the specific heat treatment processes of commercial as-cast superalloys are treated as empirical proprietary knowledge by superalloy designers and producers.

To promote chemical homogeneity and eliminate coring, as well as achieve microstructural uniformity, as-cast alloys undergo solution heat treatment. To obtain the desired uniform $\gamma / \gamma^{\prime}$ microstructure, the solution heat treatment is followed by $\gamma^{\prime}$ precipitation aging. The solution treatment should dissolve the $\gamma^{\prime}$ phase (both within the dendrites and interdendritic eutectic) into the $\gamma$ matrix by either isothermal or stepwise heat treatment, between the solvus and solidus temperatures, which is commonly referred to as 'solutioning window' [7], followed by quenching. The aging treatment involves holding the alloy at sub-solvus temperatures to obtain fine and uniform $\gamma^{\prime}$ precipitates within the $\gamma$ matrix. To promote a bimodal distribution of $\gamma^{\prime}$ phase, aging often involves high temperature primary aging, followed by lower temperature secondary aging.

Despite the above understanding, it is challenging to design solution heat treatments for new superalloys because of the following reasons.
1) Differential Scanning Calorimetry (DSC) is generally employed to obtain phase transformation temperatures. However, it is difficult to identify solvus and solidus temperatures of an ascast superalloy from the DSC profiles because of the interference of these transformations due to chemical heterogeneity [8].

2) It may be possible to resolve solidus and solvus peaks in a DSC thermograph following some degree of homogenization. However, these phase transformation temperatures not only vary with the heating or cooling rate but also with the degree of homogenization [9].

3) A highly segregated as-cast microstructure may have a solidus temperature lower than the solvus temperature. Under such a circumstance, a complete solutionizing heat treatment is considered impossible [10]. It is not uncommon that segregation of trace elements $\mathrm{P}, \mathrm{S}, \mathrm{Si}, \mathrm{B}$ and $\mathrm{Hf}$ promote incipient melting in the interdendritic region at very low temperatures [11-13].

4) The complete dissolution of eutectic $\gamma^{\prime}$ is difficult because of its coarse blocky morphology; a low surface area per volume makes it dissolve very slowly into $\gamma$ matrix [14].

The purpose of this research is to propose an efficient procedure for designing solutionizing-homogenizing heat treatments for heavily alloyed SX superalloys. The application of the proposed procedure is illustrated utilizing a newly designed experimental single crystal superalloy with significant refractory content. Stepwise heat treatments followed by microstructural analysis are employed to identify the solutioning window. The effects of holding time within and outside this solutioning window are discussed using EPMA (Electron Probe Microanalysis) and phase fraction analysis. Based on the results and analyses, a new solutionizing-homogenizing heat treatment approach is proposed.

\section{Experimental Material and Methods}

An experimental nickel base superalloy based on PWA 1480, with the nominal composition listed in Table I was used for the present research. The alloy was cast with a withdrawal rate of $5.65 \times 10^{-5}$ $\mathrm{m} / \mathrm{s}(8.0 \mathrm{in} / \mathrm{hr})$ into SX bars of $16 \mathrm{~mm}$ diameter and $200 \mathrm{~mm}$ length in a Bridgman furnace using PWA 1484 SX starter seeds [4]. The SX bars with the longitudinal axes along $<001>$ were sectioned in the transverse direction to obtain discs of approximately $6 \mathrm{~mm}$ thickness.

Table I: Nominal composition (wt \%) of experimental superalloy

\begin{tabular}{ccccccccc}
\hline $\mathrm{Ta}$ & $\mathrm{W}$ & $\mathrm{Re}$ & $\mathrm{Co}$ & $\mathrm{Mo}$ & $\mathrm{Cr}$ & $\mathrm{Ti}$ & $\mathrm{Al}$ & $\mathrm{Ni}$ \\
\hline 12 & 2 & 2 & 5 & 2 & 7.5 & 1 & 5 & Balance \\
\hline
\end{tabular}


Table II: Heat treatment experiments

\begin{tabular}{|c|c|}
\hline Expt. No. & Heat Treatment \\
\hline 1 & $1170^{\circ} \mathrm{C} / 15 \mathrm{~h}+1250^{\circ} \mathrm{C} / 2 \mathrm{~h}+1280^{\circ} \mathrm{C} / 2 \mathrm{~h}+1300^{\circ} \mathrm{C} / 2 \mathrm{~h}+1310^{\circ} \mathrm{C} / 2 \mathrm{~h}$ \\
2 & $1170^{\circ} \mathrm{C} / 15 \mathrm{~h}+1250^{\circ} \mathrm{C} / 2 \mathrm{~h}+1280^{\circ} \mathrm{C} / 5 \mathrm{~h}+1300^{\circ} \mathrm{C} / 2 \mathrm{~h}+1310^{\circ} \mathrm{C} / 2 \mathrm{~h}+1315^{\circ} \mathrm{C} / 2 \mathrm{~h}+1320^{\circ} \mathrm{C} / 2 \mathrm{~h}$ \\
3 & $1170^{\circ} \mathrm{C} / 2 \mathrm{~h}+1250^{\circ} \mathrm{C} / 2 \mathrm{~h}+1280^{\circ} \mathrm{C} / 15 \mathrm{~h}+1300^{\circ} \mathrm{C} / 2 \mathrm{~h}+1310^{\circ} \mathrm{C} / 2 \mathrm{~h}+1320^{\circ} \mathrm{C} / 2 \mathrm{~h}$ \\
4 & $1170^{\circ} \mathrm{C} / 2 \mathrm{~h}+1250^{\circ} \mathrm{C} / 2 \mathrm{~h}+1280^{\circ} \mathrm{C} / 5 \mathrm{~h}+1300^{\circ} \mathrm{C} / 2 \mathrm{~h}+1310^{\circ} \mathrm{C} / 5 \mathrm{~h}+1315^{\circ} \mathrm{C} / 15 \mathrm{~h}$ \\
5 & $1170^{\circ} \mathrm{C} / 2 \mathrm{~h}+1250^{\circ} \mathrm{C} / 2 \mathrm{~h}+1280^{\circ} \mathrm{C} / 5 \mathrm{~h}+1300^{\circ} \mathrm{C} / 5 \mathrm{~h}+1310^{\circ} \mathrm{C} / 15 \mathrm{~h}$ \\
6 & $1280^{\circ} \mathrm{C} / 2 \mathrm{~h}+1295^{\circ} \mathrm{C} / 2 \mathrm{~h}+1305^{\circ} \mathrm{C} / 2 \mathrm{~h}+1310^{\circ} \mathrm{C} / 2 \mathrm{~h}$ \\
7 & $1280^{\circ} \mathrm{C} / 2 \mathrm{~h}+1295^{\circ} \mathrm{C} / 2 \mathrm{~h}+1305^{\circ} \mathrm{C} / 10 \mathrm{~h}$ \\
\hline & $1280^{\circ} \mathrm{C} / 2 \mathrm{~h}+1295^{\circ} \mathrm{C} / 2 \mathrm{~h}+1305^{\circ} \mathrm{C} / 20 \mathrm{~h}$ \\
\hline
\end{tabular}

A box type radiant furnace with accurate temperature control of $\pm 1^{\circ} \mathrm{C}$ was used for heat treatments. An additional thermocouple with its bead in contact with the specimen was used to confirm the temperature measurement. Tables II lists stepwise heat treatment experiments in which each temperature step follows from the previous temperature. The temperature range of 1170 to $1320^{\circ} \mathrm{C}$ was chosen based on the DSC thermograph of the alloy obtained by Kearsey et al. [4]. To track the microstructural evolution during the stepwise heat treatments specimens were quenched in water after each step. All the experiments were performed in an air atmosphere. To avoid the interference of surface oxidation in the analysis, the specimen discs were sectioned transversely at the centre of $6 \mathrm{~mm}$ thickness and the unoxidized surfaces were used for metallographic examination. Specimens were prepared for optical microscopy by grinding to $1 \mu \mathrm{m}$ finish using standard metallographic procedures, followed by etching in a solution of $0.3 \mathrm{~g}$ molybdic acid, $10 \mathrm{ml} \mathrm{HNO}_{3}, 10 \mathrm{ml} \mathrm{HCl}$ and $15 \mathrm{ml} \mathrm{H}_{2} \mathrm{O}$.

\section{Eutectic Phase Fraction Analysis}

To track the degree of solutionizing, eutectic phase fraction analysis was carried out using the image analysis software, Image Tool ${ }^{\mathrm{TM}}$. A representative low magnification optical micrograph of the alloy obtained after each heat treatment step was converted into 16-bit grayscale format. After adjusting the brightness and contrast to delineate the dendrite and eutectic region, the grayscale format was converted into black and white threshold image using an Image Tool ${ }^{\mathrm{TM}}$ subroutine. Residual pixels corresponding to the eutectic region present in the black and white images were removed manually using a pixel editing tool. Finally, areas corresponding to dendrite and eutectic regions were obtained by counting the pixels from the black and white regions.

\section{Electron Probe Microanalysis (EPMA)}

It has been established that a sharp compositional gradient exists in the as-cast alloy from the interdendritic eutectic to dendrite core region along [011] type direction [4]. Hence, studying the variation of this composition profile after each heat treatment step gives an estimate of degree of homogenization and hence the effectiveness of the heat treatment step. To study the variation of composition profiles, a series of spot chemical analysis was performed with intervals of about $25 \mu \mathrm{m}$ along a line from the eutectic region to the dendrite core.
A Camebax Electron Microprobe with Wavelength Dispersive XRay (WDX) spectrometers was used for the analysis. Selected specimens ground to $1 \mu \mathrm{m}$ finish by standard metallographic techniques were used for the analysis. The electron probe with accelerating voltage, $20 \mathrm{kV}$ and beam current, $35 \mathrm{nA}$ was used for the analysis over $5 \mu \mathrm{m} \times 5 \mu \mathrm{m}$ raster with total counting time of $60 \mathrm{~s}$ for each element. A well characterized suite of pure metals and minerals was used for calibration. The matrix correction software, Cameca PAP, was used for converting X-ray data into elemental weight percent. The limits of background noise levels were carefully determined by running wavelength scans on either side of the peak position of each analyzed element. As a result, highly accurate quantitative results were obtained including elements added in small amounts $(\mathrm{Re}, \mathrm{Ti}, \mathrm{W})$.

\section{Results and Discussion}

\section{$\underline{\text { Microstructural Analysis }}$}

The as-cast microstructure of the alloy is shown in Figure 1. The dendrite core microstructure is fine and uniform, while interdendritic region contains a cellular eutectic phase.

Figure 2 shows the microstructural developments during the stepwise heat treatment identified as experiment 1 in Table 2 . The first microstructural change occurs during the $1250^{\circ} \mathrm{C}$ step as the interdendritic region around the eutectic phase becomes denuded of fine $\gamma^{\prime}$ precipitates, indicating that solutioning begins at the interdendritic region. Kearsey et al. [2,4] studied and confirmed this using scanning electron microscopy. However, during the higher temperature steps, this $\gamma^{\prime}$ denuded region does not spread to dendrites. Instead, dendritic solutioning begins at the core region during the $1280^{\circ} \mathrm{C}$ step (Figure 2b) followed by complete solutioning of dendrites during the $1300^{\circ} \mathrm{C}$ step leaving behind undissolved blocky eutectic at the interdendritic region (Figure 2c). During the $1310^{\circ} \mathrm{C}$ step, incipient melting occurs in the interdendritic region adjacent to the residual eutectic (Figure 2d). From these observations, it may be approximated that $\gamma^{\prime}$-solvus temperature is $1290^{\circ} \mathrm{C}$ and the solidus is $1310^{\circ} \mathrm{C}$ and hence, the solutioning window is approximately $1290^{\circ} \mathrm{C}$ to $1310^{\circ} \mathrm{C}$. 

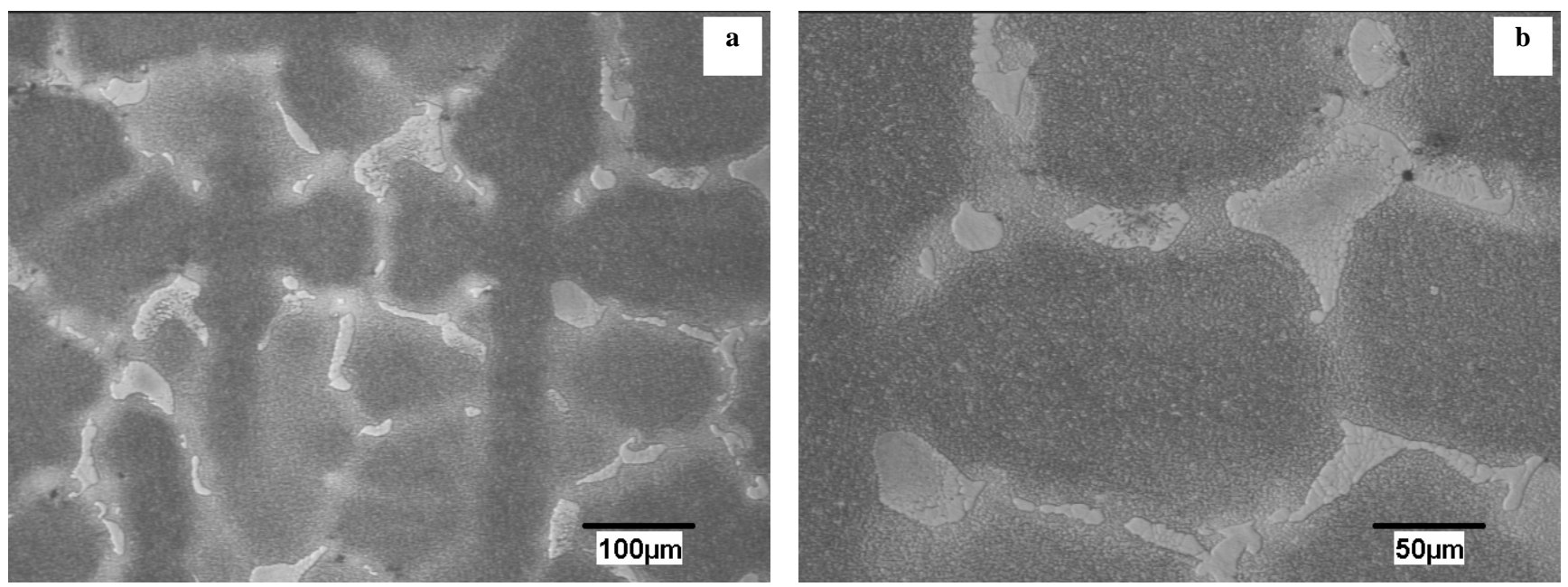

Figure 1: As-cast microstructure of the alloy showing: a) dendritic structure, b) cellular eutectic phase at the interdendritic region
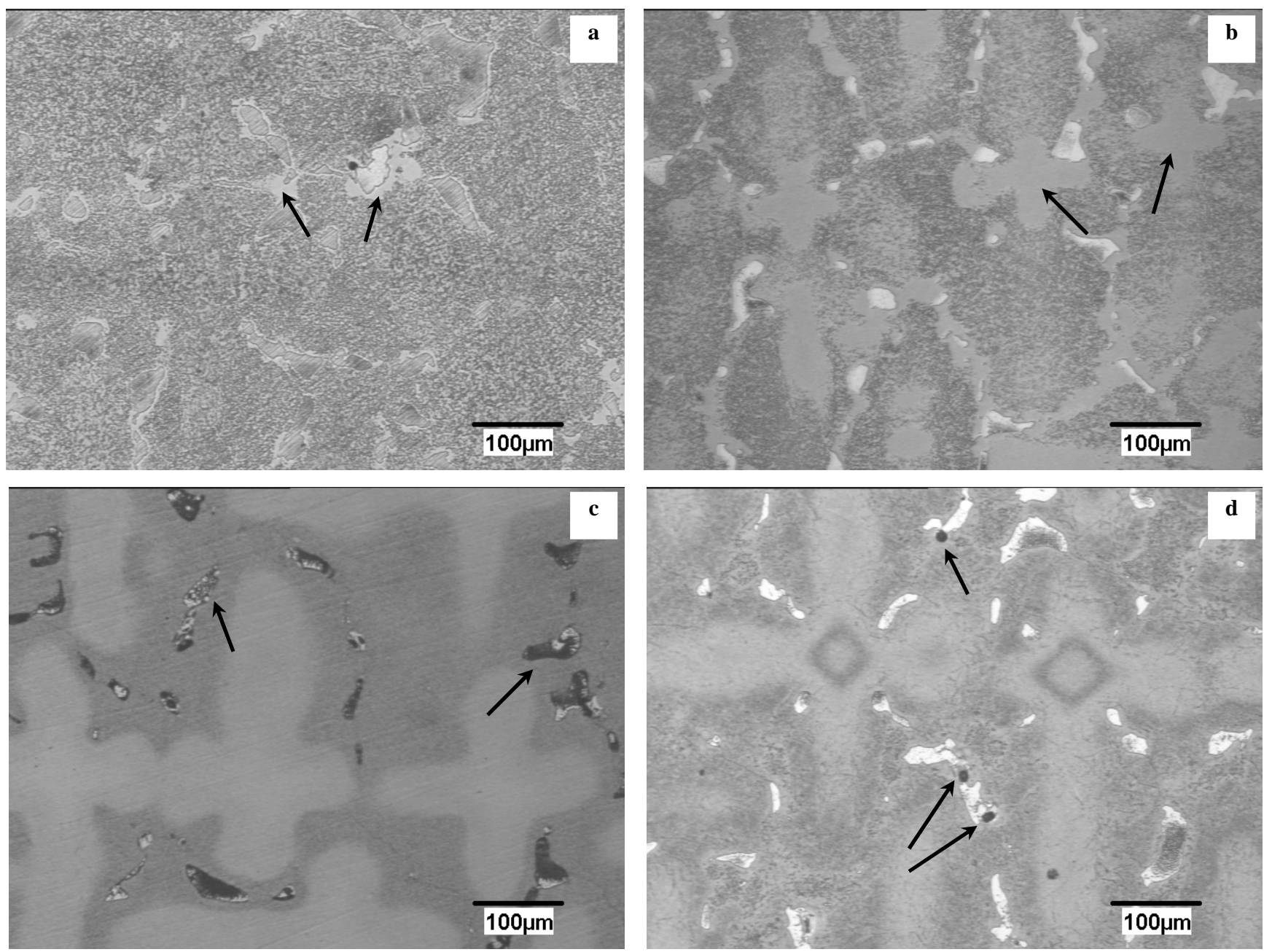

Figure 2: Microstructure of the alloy after: a) $1170^{\circ} \mathrm{C} / 15 \mathrm{~h}+1250^{\circ} \mathrm{C} / 2 \mathrm{~h}$ showing denuded region around the eutectic, b) same as a) $+1280^{\circ} \mathrm{C} / 2 \mathrm{~h}$ showing solutioning at dendrite cores, c) same as b) $+1300^{\circ} \mathrm{C} / 2 \mathrm{~h}$ showing the residual eutectic phase between fully solutionized dendrites, d) same as $\mathrm{c})+1310^{\circ} \mathrm{C} / 2 \mathrm{~h}$ showing incipient melting at the interdendritic region 

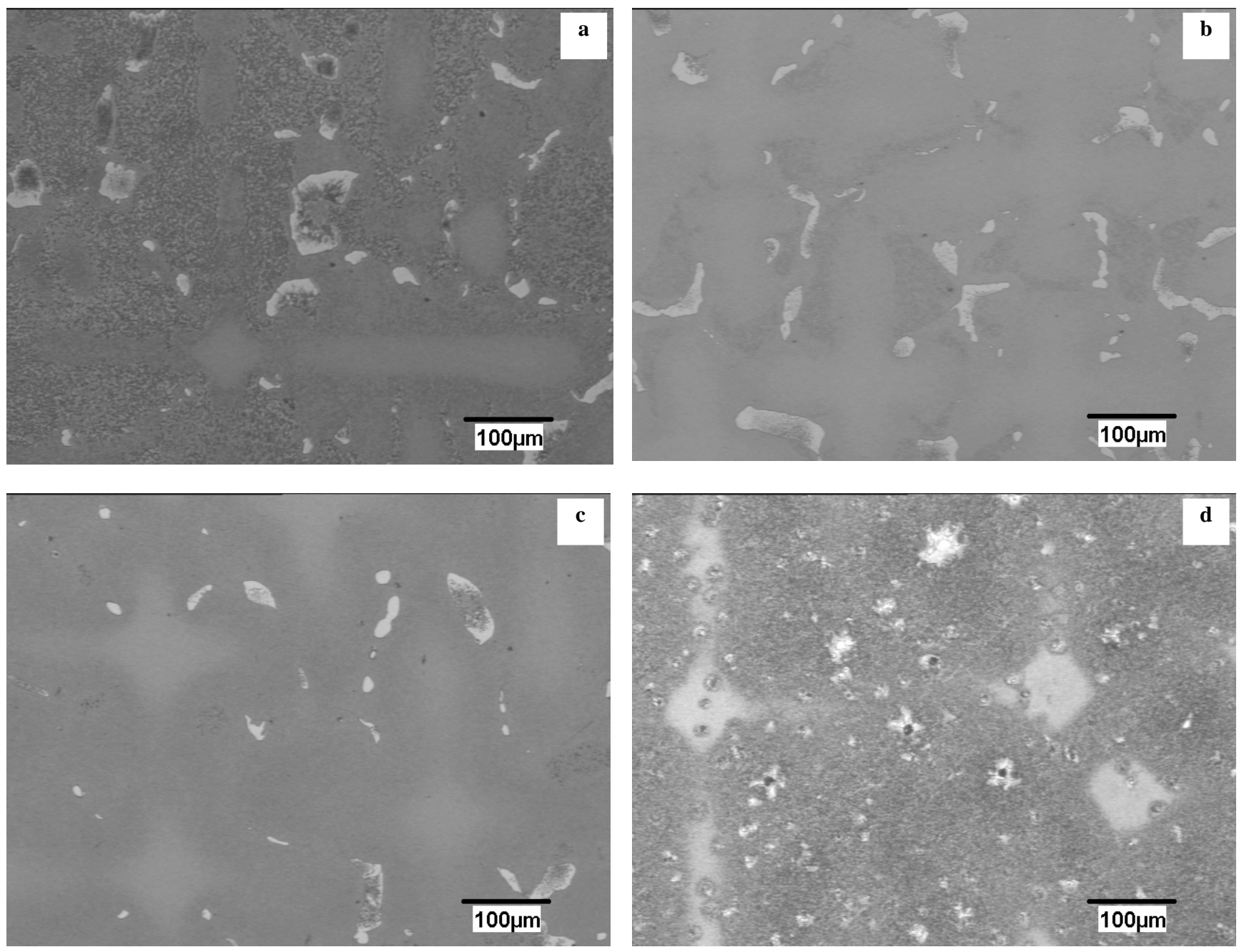

Figure 3: Microstructures of the alloy after: a) $1170^{\circ} \mathrm{C} / 15 \mathrm{~h}+1250^{\circ} \mathrm{C} / 2 \mathrm{~h}+1280 / 5 \mathrm{~h}+1300^{\circ} \mathrm{C} / 2 \mathrm{~h}$, b) same as a) $+1310^{\circ} \mathrm{C} / 2 \mathrm{~h}$ showing no sign of incipient melting, c) same as b) $+1315^{\circ} \mathrm{C} / 2 \mathrm{~h}$ showing reduced eutectic phase fraction, d) same as c) $+1320^{\circ} \mathrm{C} / 2 \mathrm{~h}$ showing incipient melting.

The results of experiment 2 depict the effects of extended holding $(5 \mathrm{~h})$ at a sub-solvus temperature of $1280^{\circ} \mathrm{C}$. As observed from Figure 3, there is no sign of incipient melting of the alloy up to $1315^{\circ} \mathrm{C}$. However, at $1320^{\circ} \mathrm{C}$, the alloy shows considerable incipient melting at both interdendritic region and within the dendrites.

Figure 4 shows the occurrence of incipient melting after $1320^{\circ} \mathrm{C}$ step of experiment 3. A careful observation of microstructures of the alloy, before and after $1320^{\circ} \mathrm{C}$ step, confirms that the residual eutectic blocks at the interdendritic region undergo a eutectic reaction giving rise to cellular colonies.

From experiments 1, 2 and 3, it is clear that prolonged sub-solvus holding $\left(1280^{\circ} \mathrm{C} / 2 \mathrm{~h}, 5 \mathrm{~h}, 15 \mathrm{~h}\right)$ helps in raising solidus temperature slightly but not monotonically. Experiments 4 and 5 revealed incipient melting during prolonged holding at temperatures $1315^{\circ} \mathrm{C}, 1310^{\circ} \mathrm{C}$ respectively. Figure 5 illustrates how extended holding promotes incipient melting.
Figure 6 shows the results of experiments 6,7 and 8 involving heat treatment steps within the solution heat treatment window $\left(1290-1310^{\circ} \mathrm{C}\right)$. A systematic reduction in the eutectic fraction is evident from the micrographs indicating that $\gamma^{\prime}$ solutioning is very effective within the window. However, a careful observation of figure $6 \mathrm{~d}$ indicates onset of incipient melting and hence confirms the deleterious effect of prolonged holding.

From the microstructural observations, it may be summarized that $\gamma^{\prime}$ solutioning is effective within the solutioning window and that irrespective of the degree of homogenization or the thermal history of the alloy, extended holding in the vicinity of solidus temperature leads to incipient melting. 

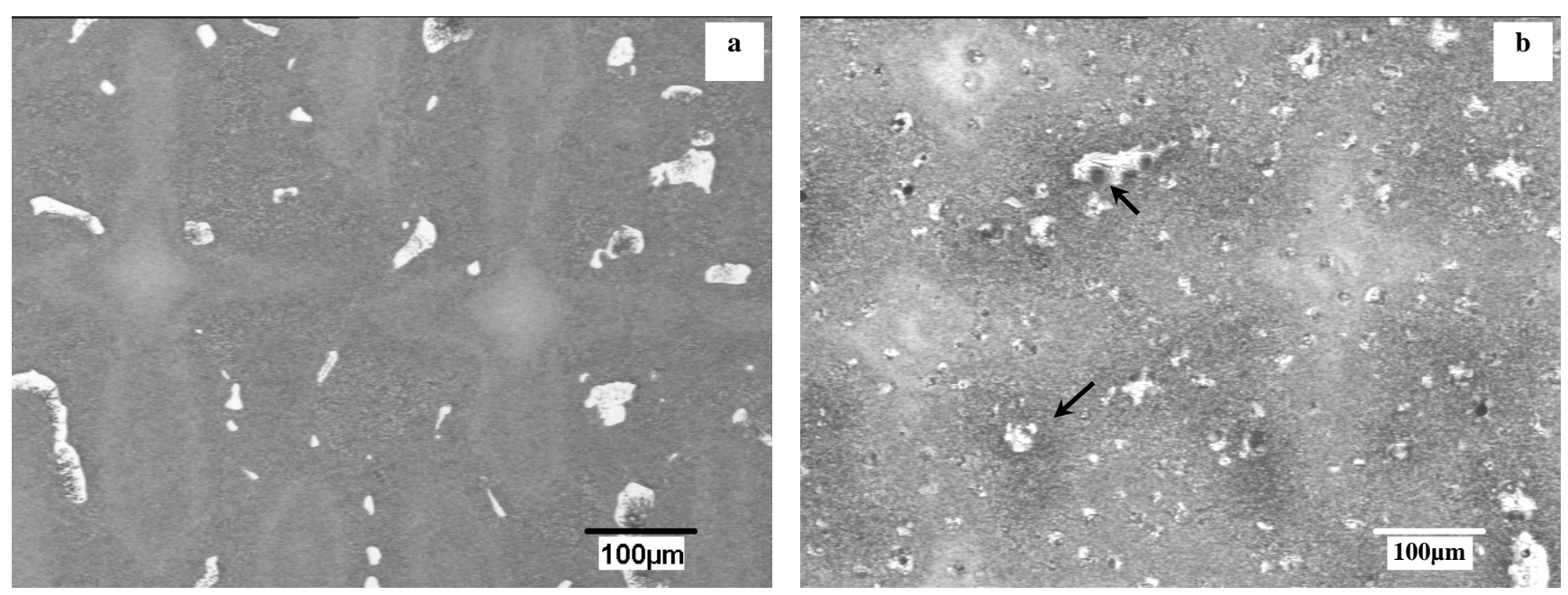

Figure 4: Microstructures of the alloy after: a) $1170^{\circ} \mathrm{C} / 2 \mathrm{~h}+1250^{\circ} \mathrm{C} / 2 \mathrm{~h}+1280^{\circ} \mathrm{C} / 15 \mathrm{~h}+1300^{\circ} \mathrm{C} / 2 \mathrm{~h}+1310^{\circ} \mathrm{C} / 2 \mathrm{~h}$, b) same as a) $+1320^{\circ} \mathrm{C} / 2 \mathrm{~h}$ showing a burst of incipient melting.
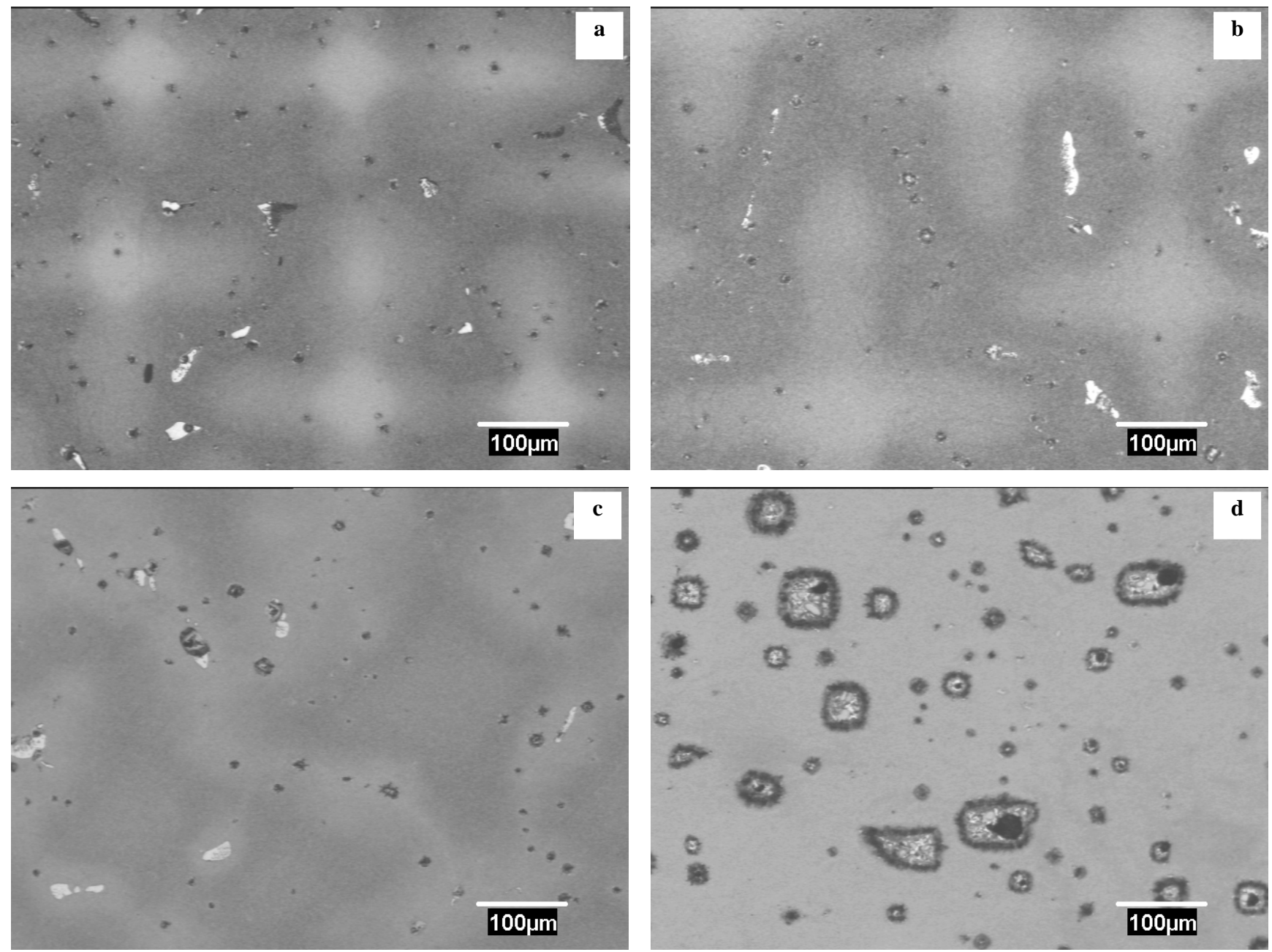

Figure 5: Microstructural change of the alloy after the step heat treatment $1170^{\circ} \mathrm{C} / 2 \mathrm{~h}+1250^{\circ} \mathrm{C} / 2 \mathrm{~h}+1280^{\circ} \mathrm{C} / 5 \mathrm{~h}+1300^{\circ} \mathrm{C} / 5 \mathrm{~h}$ followed by holding at $1310^{\circ} \mathrm{C}$ for: a) $\left.\left.\left.2 \mathrm{~h}, \mathrm{~b}\right) 5 \mathrm{~h}, \mathrm{c}\right) 10 \mathrm{~h}, \mathrm{~d}\right) 15 \mathrm{~h}$ showing a systematic development of incipient melting. 

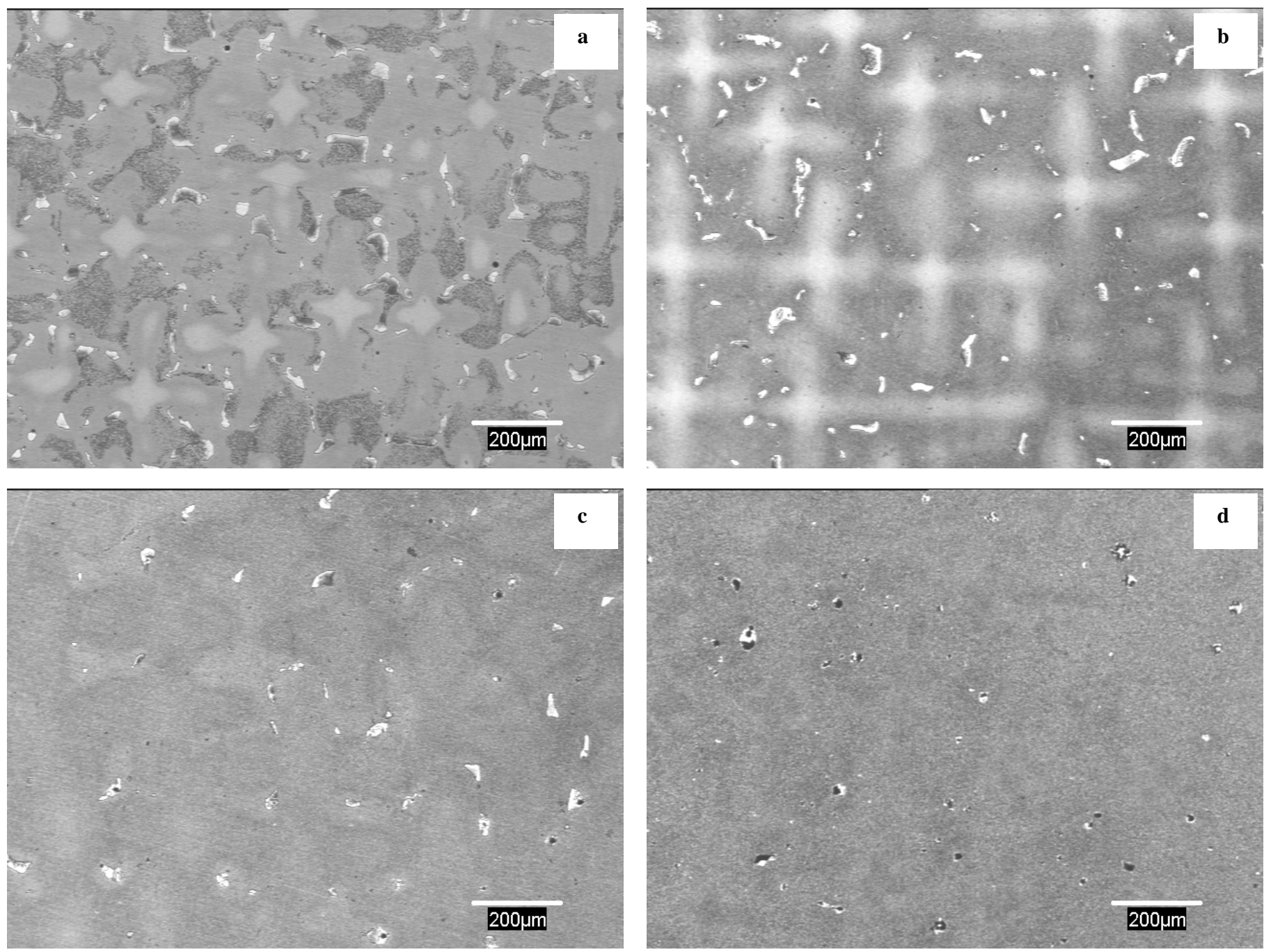

Figure 6: Microstructural change of the alloy after: a) $1280^{\circ} \mathrm{C} / 2 \mathrm{~h}+1295^{\circ} \mathrm{C} / 2 \mathrm{~h}, \mathrm{~b}$ ) same as a) $+1305^{\circ} \mathrm{C} / 2 \mathrm{~h}$, c) same as a) $+1305^{\circ} \mathrm{C} / 10 \mathrm{~h}$, d) same as a) $+1305^{\circ} \mathrm{C} / 15 \mathrm{~h}$ showing a systematic reduction of eutectic phase.

Table III: Eutectic phase fraction analysis

\begin{tabular}{|c|l|l|}
\hline $\begin{array}{c}\text { Expt. } \\
\text { No }\end{array}$ & Heat Treatment Step & $\begin{array}{l}\text { Eutectic Phase } \\
\text { Fraction (\%) }\end{array}$ \\
\hline- & As-cast & 6.99 \\
\hline 1 & $1280^{\circ} \mathrm{C} / 2 \mathrm{~h}$ & 3.29 \\
\hline 2 & $1280^{\circ} \mathrm{C} / 5 \mathrm{~h}$ & 3.38 \\
\hline 3 & $1280^{\circ} \mathrm{C} / 15 \mathrm{~h}$ & 4.23 \\
\hline 6 & $1280^{\circ} \mathrm{C} / 2 \mathrm{~h}, 1295^{\circ} \mathrm{C} / 2 \mathrm{~h}$, & $4.76,3.78$, \\
\hline 7 & $1305^{\circ} \mathrm{C} / 2 \mathrm{~h}$ & 2.33 \\
\hline 8 & $1305^{\circ} \mathrm{C} / 10 \mathrm{~h}$ & 1.26 \\
\hline & $1305^{\circ} \mathrm{C} / 20 \mathrm{~h}$ & 0.91 \\
\hline
\end{tabular}

\section{$\underline{\text { Eutectic Phase Fraction Analysis }}$}

Eutectic phase fraction analyses performed on selected specimens are listed in Table III. Figure $7 \mathrm{a}$ and $7 \mathrm{~b}$ illustrate the effects of extended holding on the solutioning of eutectic at a sub-solvus temperature, $1280^{\circ} \mathrm{C}$ and a super-solvus temperature, $1305^{\circ} \mathrm{C}$. Figure $7 \mathrm{c}$ shows the effect of increase in the holding temperature. Figure $7 \mathrm{a}$ indicates the unusual trend of increase in the eutectic fraction with increase in the holding time. This implies that an extended holding at $1280^{\circ} \mathrm{C}$ stabilizes the eutectic phase rather than dissolving it. However, extended holding above the solvus temperature shows a systematic reduction in the eutectic fraction, Figure $7 \mathrm{~b}$. The stepwise heat treatment with increase in the holding temperature also shows a monotonic reduction in the eutectic phase, Figure 7c. This indicates that a sub-solvus heat treatment has no beneficial effect on the dissolution of eutectic phase while a super-solvus heat treatment is beneficial. Hence, a stepwise heat treatment between solvus and solidus is an effective solutioning approach. This window is generally narrow for superalloys with high refractory content. Hence, stepwise heat treatment within the window would require a large number of incremental temperature steps. Hence, a slow and continuous heating is more practical solutioning method. As experiment 8 is the most effective heat treatment with residual eutectic fraction of less than $1 \%$. Total time required for achieving this solution is approximately $25 \mathrm{~h}$ over a temperature range of $25^{\circ} \mathrm{C}(1280$ $1305^{\circ} \mathrm{C}$ ). Hence approximately $1^{\circ} \mathrm{C} / \mathrm{h}$ should be an optimum heating rate of for the continuous heating. 


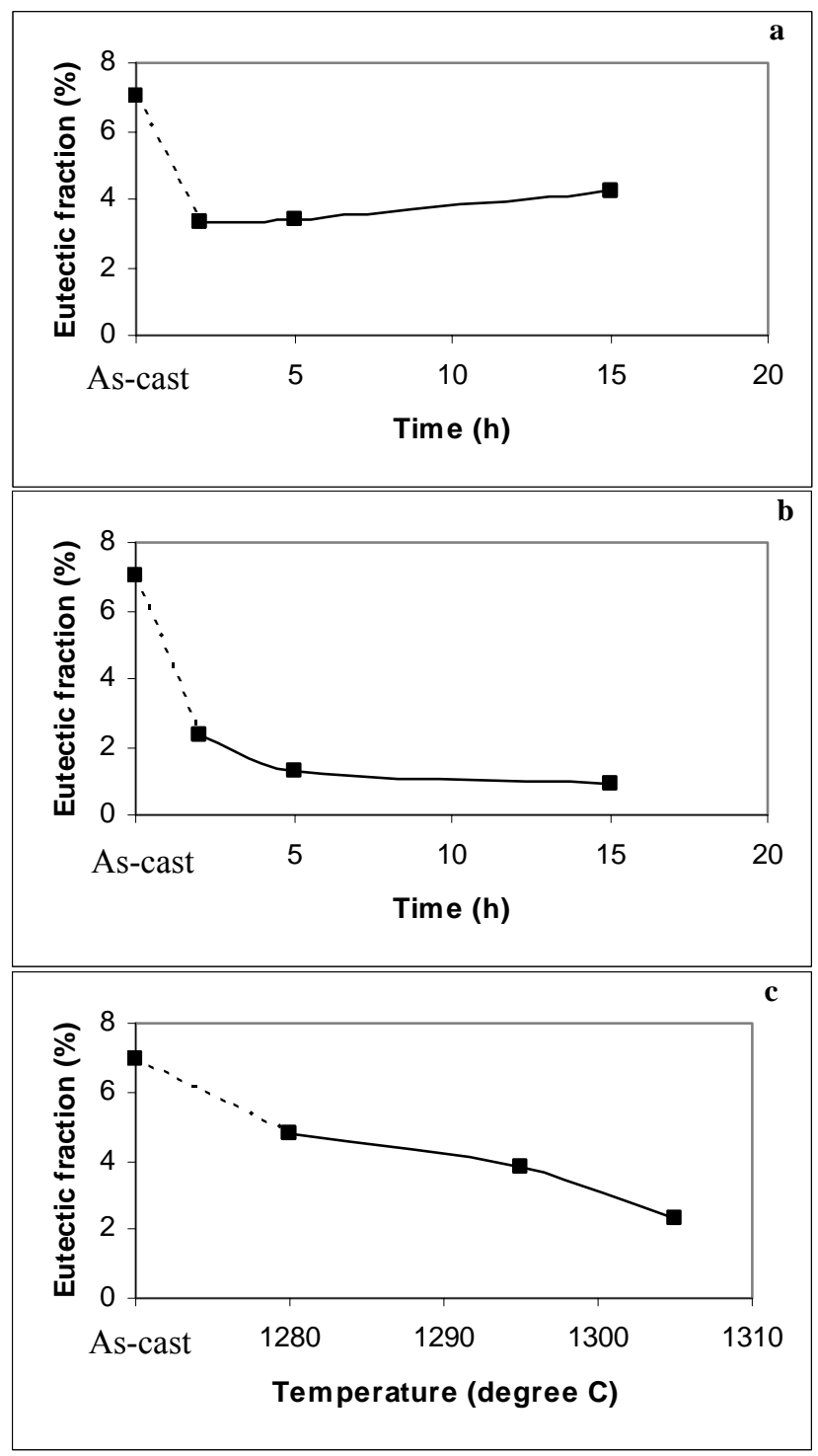

Figure 7: A comparison of variation of eutectic fraction with: a) holding time at $1280^{\circ} \mathrm{C}$ from experiments 1,2 and 3 .

b) holding time at $1305^{\circ} \mathrm{C}$ from experiments 6,7 and 8 and c) holding temperature from experiment 6 .

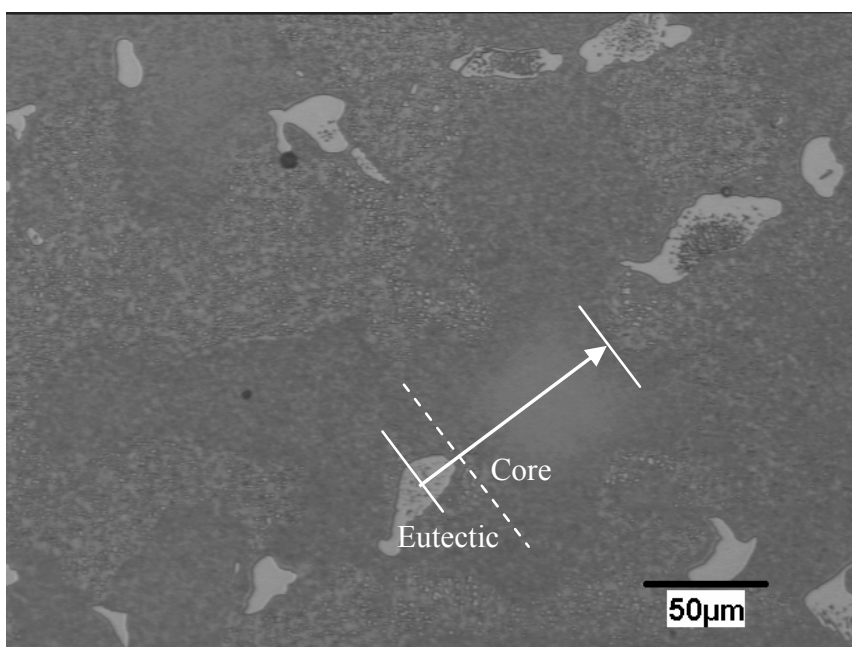

Figure 8: An illustration of EPMA composition profile measurement

\section{Electron Probe Microanalysis (EPMA)}

An illustration of EPMA measurements from eutectic region to the dendrite core is shown in Figure 8. The composition profiles of selected elements after heat treatment steps of experiment 6, 7 and 8 are shown in figures 9 and 10. As evident from the figures, there is a sharp gradient between eutectic and core regions. Figure 9 indicates that this gradient decreases with increase in the heat treatment temperature. Conversely, Figure 10 indicates that prolonged holding increases the eutectic to core gradient.

The degree of homogenization can be expressed as the difference between the maximum point and the minimum point on the profile. Lower the difference, flatter the profile, more homogeneous the alloy. Table IV gives variation in degree of homogenization with increase in holding temperature and time. There is a clear trend of increased homogenization with increased heat treatment temperature from as-cast to $1305^{\circ} \mathrm{C}$. On the other hand, prolonged isothermal holding from $2 \mathrm{~h}$ to $20 \mathrm{~h}$ at $1305^{\circ} \mathrm{C}$ indicates a decreasing homogenization trend. If the profiles in figure 9 and 10 are carefully observed, it is clear that the dendrite core quickly homogenizes and attains the nominal composition with an increase in temperature. Also, the core remains homogenized during extended isothermal holding. However, during prolonged isothermal holding, the eutectic region diverges from the nominal composition of the alloy. Such an unusual behavior at the eutectic region has been reported as up-hill diffusion [15]. The present work however confirms that up-hill diffusion leads to incipient melting during long isothermal holding (Figure $6 \mathrm{~d}$ ). The results of electron microprobe analysis suggest that stepwise heat treatment with increasing temperature is more beneficial than the isothermal heat treatment. 
Table IV: Variation of homogenization with heat treatment

\begin{tabular}{|c|c|c|c|c|c|c|}
\hline \multirow{3}{*}{ Element } & \multirow{3}{*}{$\begin{array}{c}\text { Profile } \\
\text { Statistics }\end{array}$} & \multicolumn{5}{|c|}{ Concentration (wt \%) } \\
\hline & & \multirow{2}{*}{$\begin{array}{l}\text { As- } \\
\text { cast }\end{array}$} & \multicolumn{2}{|c|}{ Expt. 6} & \multirow{2}{*}{$\begin{array}{c}\text { Expt. } 7 \\
1305^{\circ} \mathrm{C} \\
/ 10 \mathrm{~h}\end{array}$} & \multirow{2}{*}{$\begin{array}{l}\text { Expt. } 8 \\
1305^{\circ} \mathrm{C} \\
120 \mathrm{~h}\end{array}$} \\
\hline & & & $\begin{array}{c}1295^{\circ} \mathrm{C} \\
12 \mathrm{~h}\end{array}$ & $\begin{array}{c}1305^{\circ} \mathrm{C} \\
12 \mathrm{~h}\end{array}$ & & \\
\hline \multirow{3}{*}{ Al } & $\max$ & 6.13 & 5.969 & 5.545 & 5.98 & 6.414 \\
\hline & $\min$ & 4.55 & 4.668 & 4.715 & 4.774 & 4.711 \\
\hline & Diff & 1.58 & 1.301 & 0.83 & 1.206 & 1.703 \\
\hline \multirow{3}{*}{$\mathrm{Cr}$} & $\max$ & 8.20 & 8.067 & 7.685 & 7.886 & 7.695 \\
\hline & $\min$ & 2.77 & 3.975 & 4.651 & 4.653 & 2.716 \\
\hline & Diff & 5.43 & 4.092 & 3.034 & 3.233 & 4.979 \\
\hline \multirow{3}{*}{$\mathrm{Ni}$} & $\max$ & 66.05 & 65.343 & 64.492 & 65.401 & 67.35 \\
\hline & $\min$ & 61.87 & 61.626 & 61.963 & 63.155 & 62.948 \\
\hline & Diff & 4.17 & 3.717 & 2.529 & 2.246 & 4.402 \\
\hline \multirow{3}{*}{ Co } & $\max$ & 5.17 & 5.261 & 5.074 & 5.201 & 5.216 \\
\hline & $\min$ & 3.65 & 4.044 & 4.27 & 4.252 & 3.724 \\
\hline & Diff & 1.52 & 1.217 & 0.804 & 0.949 & 1.492 \\
\hline \multirow{3}{*}{$\mathrm{Ti}$} & $\max$ & 1.65 & 1.228 & 1.229 & 1.225 & 1.347 \\
\hline & $\min$ & 0.66 & 0.922 & 0.999 & 0.977 & 1.001 \\
\hline & Diff & 0.99 & 0.306 & 0.23 & 0.248 & 0.346 \\
\hline \multirow{3}{*}{$\mathbf{R e}$} & $\max$ & 2.80 & 2.6 & 2.148 & 2.386 & 2.261 \\
\hline & $\min$ & 0.29 & 0.735 & 0.946 & 0.928 & 0.316 \\
\hline & Diff & 2.51 & 1.865 & 1.202 & 1.458 & 1.945 \\
\hline \multirow{3}{*}{$\mathrm{Ta}$} & $\max$ & 18.21 & 15.411 & 14.457 & 15.252 & 17.104 \\
\hline & $\min$ & 9.41 & 10.885 & 11.913 & 11.89 & 11.967 \\
\hline & Diff & 8.81 & 4.526 & 2.544 & 3.362 & 5.137 \\
\hline \multirow{3}{*}{ Mo } & $\max$ & 2.08 & 1.967 & 1.894 & 1.881 & 1.947 \\
\hline & $\min$ & 0.50 & 0.878 & 1.28 & 0.978 & 0.399 \\
\hline & Diff & 1.58 & 1.089 & 0.614 & 0.903 & 1.548 \\
\hline \multirow{3}{*}{$\mathbf{W}$} & $\max$ & 2.83 & 2.678 & 2.102 & 2.263 & 2.195 \\
\hline & $\min$ & 0.63 & 1.313 & 1.221 & 1.233 & 0.82 \\
\hline & Diff & 2.20 & 1.365 & 0.881 & 1.03 & 1.375 \\
\hline
\end{tabular}
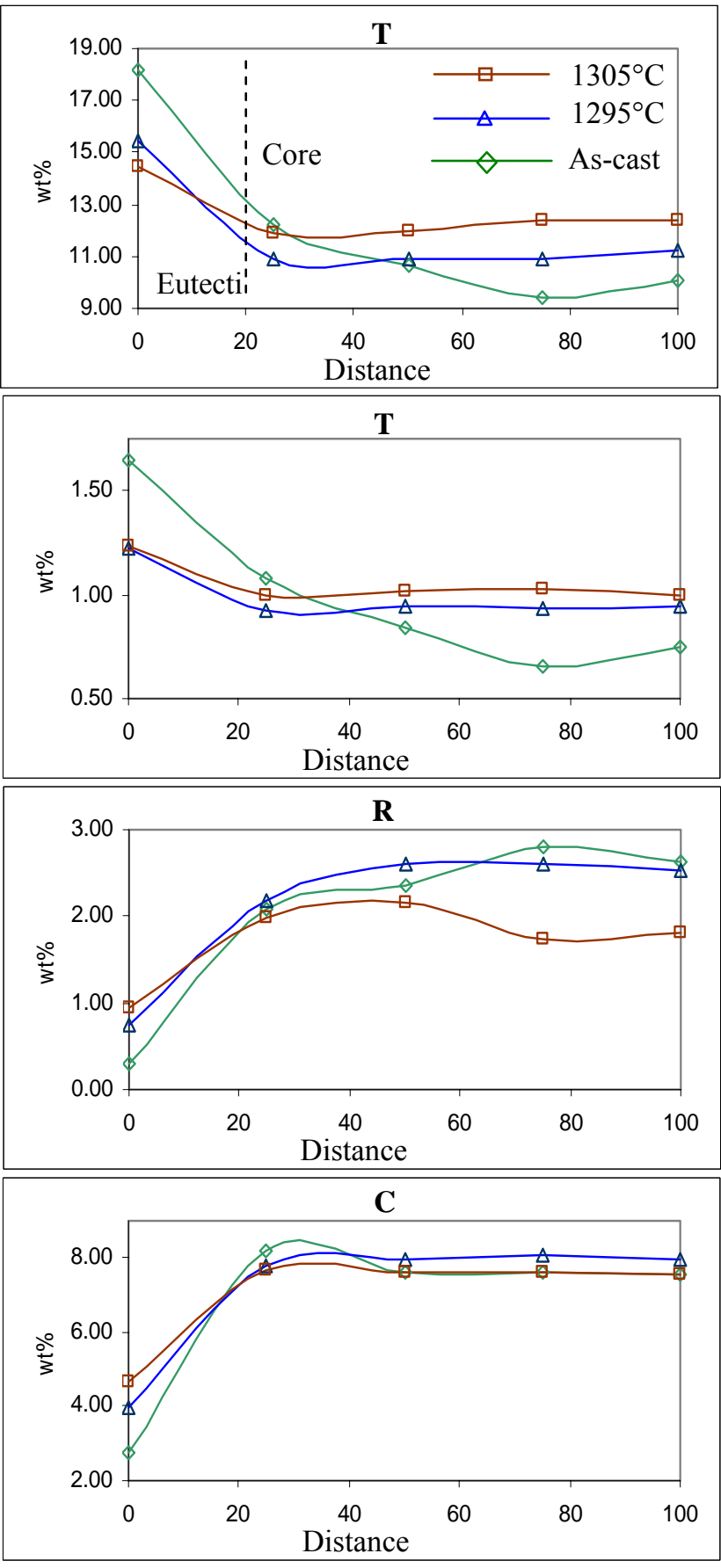

Figure 9: Composition profile from eutectic to core region showing increased homogenization with increased holding temperature 

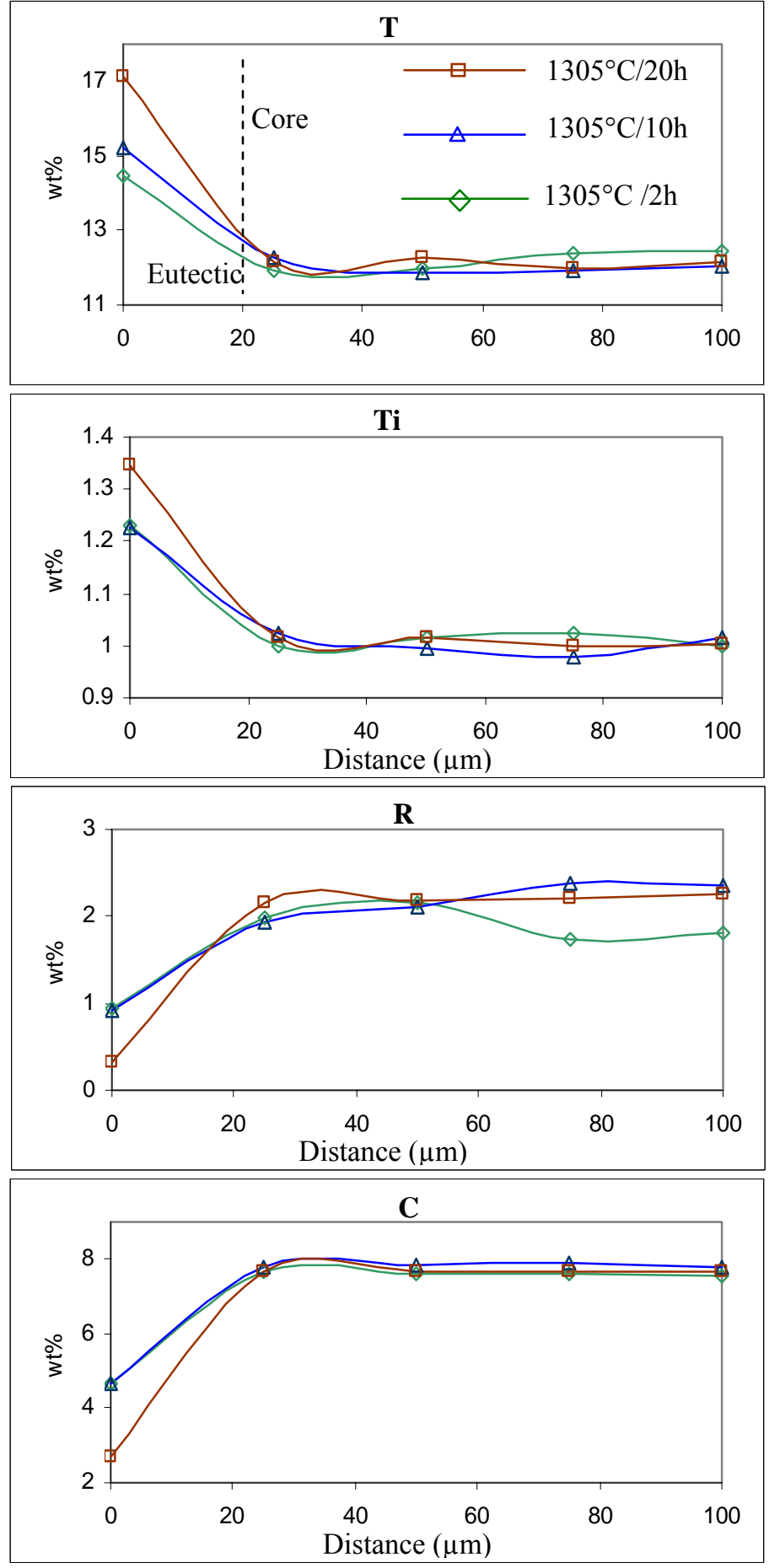

Figure 10: Isothermal composition profiles from eutectic to core region showing a reduction in homogenization with extended holding at $1305^{\circ} \mathrm{C}$.
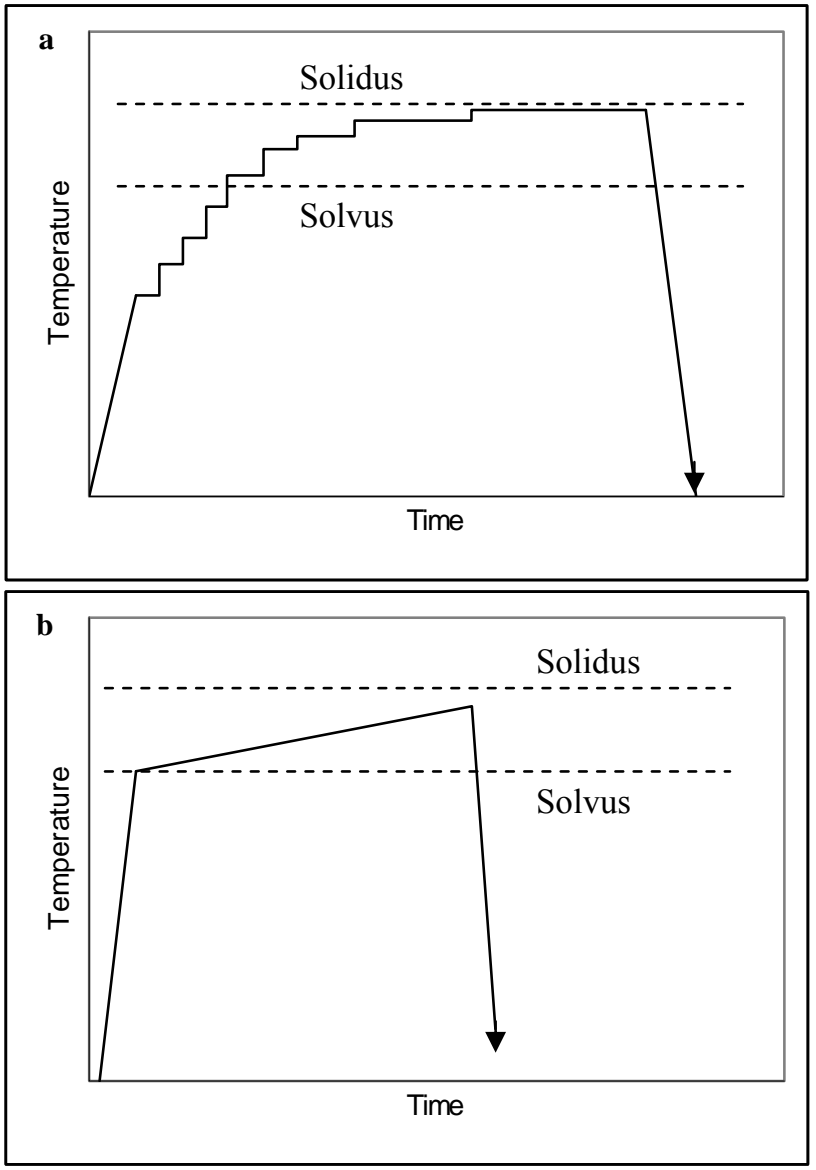

Figure 11: A comparison of a) Traditional step-wise heat treatment and b) proposed heat treatment scheme.

\section{Summary and Conclusions}

The heat treatment response of an experimental SX superalloy studied by stepwise heat treatments between 1170 to $1320^{\circ} \mathrm{C}$ may be summarized as follows.

Sub-solvus homogenization heat treatments help in elevating the incipient melting temperature marginally. Extended isothermal holding at a sub-solvus temperature has no beneficial effect on the dissolution of eutectic $\gamma^{\prime}$. Extended holding at and above solidus temperature leads to incipient melting, irrespective of the thermal history of the alloy.

Both extended holding and isothermal holding between solvus and solidus temperatures homogenizes the dendrite core quickly. However, eutectic region indicate up-hill diffusion during isothermal holding leading to incipient melting. Hence, continuous heating at a slow heating rate between the solvus and solidus seems to be the favorable condition for the complete solutioning and homogenization of the alloy without incipient melting. Hence a new solutionizing-homogenizing heat treatment scheme, compared to the usual traditional stepwise heat treatment, shown in Figure 11 is proposed. 
The procedure for designing an effective homogenizingsolutioning heat treatment for a newly designed alloy with heavy refractory content would be:

1. Decide the temperature range of interest from the DSC thermograph of the as-cast alloy.

2. Determine the approximate solvus and solidus temperatures by stepwise heat treatments with increasing temperature and the constant holding time of $2 \mathrm{~h}$.

3. Quickly raise the temperature of the specimen to the solvus temperature.

4. Heat the specimen at a slow rate of about $1^{\circ} \mathrm{C} / \mathrm{h}$.

5. Quench just before reaching the solidus temperature.

\section{Acknowledgements}

The financial support provided by NSERC and NRC for this project is greatly appreciated. Authors are thankful to the IARNRC for providing metallographic laboratory facility at the Structures and Materials Performance Laboratory. Thanks are due to Peter Jones of the Department of Earth Sciences, Carleton University for assisting in microprobe analysis.

\section{References}

[1] M. Durand-Charre, The Microstructure of Superalloys (Gordon and Breach Science Publishers, Amsterdam), 1997.

[2] R.M. Kearsey, J.C. Beddoes, P. Jones, and P. Au, "Compositional Design Considerations for Microsegregation in Single Crystal Superalloy Systems" Intermetallics 12 (2004), 903910

[3] G.L. Erickson, "The Development and Application of CMSX10" Superalloys 1996, ed. R.D. Kissinger, D.J. Deye, D.L. Anton, A.D. Cetel, M.V. Nathal, T.M. Pollock, D. Woodford, (Warrendale, PA: TMS, 1996), 35-44.

[4] R.M. Kearsey, J.C. Beddoes, P. Jones, K.M. Jansaalu, W.T. Thompson, and P. Au, "The Effects of Re, W, and Ru on the Microsegregation Behaviour in Single Crystal Superalloy Systems" Superalloys 2004, ed. K. A. Green, T. M. Pollock, H. Harada, T.E. Howson, R.C. Reed, J.J. Schirra, S. Walston (Warrendale, PA: TMS, 2004), 801-810.

[5] W.S. Walston, J.C. Schaeffer, and W.H. Murphy, "A New Type of Microstructural Instability in Superalloys - SRZ" Superalloys 1996, ed. R.D. Kissinger, D.J. Deye, D.L. Anton, A.D. Cetel, M.V. Nathal, T.M. Pollock, D. Woodford (Warrendale, PA: TMS, 1996), 9-18.

[6] G.E. Fuchs, "Solution Heat Treatment Response of a Third Generation Single Crystal Ni-base Superalloy", Materials Science and Engineering: A, 300 (2001), 52-60.

[7] E.C. Caldwell, F.J. Fela, and G.E. Fuchs, "Segregation of Elements in High Refractory Content Single Crystal Nickel Based Superalloys", Superalloys 2004, ed. K.A. Green, T.M. Pollock, H. Harada, T.E. Howson, R. C. Reed, J. J. Schirra, S. Walston (Warrendale, PA: TMS, 2004), 811-818.
[8] C.J. Burton, "Differential Thermal Analysis and the Mechanisms of Minor Additions in Superalloys", Superalloys 1976, ed. D.R. Muzyka, W.H. Couts, G.E. Wasielewsky, B. H. Kear, J.P. Stroup, R.L. Dreshfield, H. Morrow III (Warrendale, PA: TMS, 1976), 147-157.

[9] D.L. Sponseller, "Differential Thermal Analysis of Nickel Base Superalloys" Superalloys 1996, ed. R.D. Kissinger, D.J. Deye, D.L. Anton, A.D. Cetel, M.V. Nathal, T.M. Pollock, D. Woodford (Warrendale, PA: TMS, 1996), 259-266.

[10] G.S. Hillier, and H.K.D.H. Bhadeshia, "Homogenization of Single Crystal Superalloys" Perspectives in Metallurgical Development, (Sheffield Centenary Conference: Metals Society, 1984), 183-187.

[11] Y. Zhu, S. Zhang, L. Xu, J. Bi, Z. Hu, X, Xie, and C. Shi, "Superalloys with Low Segregation" Superalloys 1988, ed. S. Reichman, D.N. Duhl, G. Maurer, S. Antolovich, C. Lund, (TMS, Warrendale, PA, 1988), 703-712.

[12] Y. Zhu, S. Zhang, T. Zhang, J. Zhang, Z. Hu, X, Xie, and C. Shi, "A New Way To Improve The Superalloys", Superalloys 1992, ed. S.D. Antolovich, R.W. Stusurd, R.A. MacKay, D.L. Anton, T. Khan, R.D. Kissinger, D.L. Klarstrom (Warrendale, PA: TMS, 1992), 145-154.

[13] J.T. Guo, and L.Z. Zhou, "The Effect of Phosphorus, Sulpher and Silicon on Segregation, Solidification and Mechanical Properties of Cast Alloy 718" Superalloys 1996, ed. R.D. Kissinger, D.J. Deye, D.L. Anton, A.D. Cetel, M.V. Nathal, T.M. Pollock, D. Woodford (Warrendale, PA: TMS, 1996) 451-455

[14] S.A. Sajjadi, S.M. Zebarjid, R.I.L. Guthrie, and M. Isac, "Microstructure evolution of high-performance Ni-base superalloy GTD-111 with heat treatment parameters" Journal of Materials Processing Technology, 175 (2006) 376.

[15] M.S.A. Karunaratne, D.C. Cox, P. Carter, R.C. Reed, and K.A. Green, "Modelling of the Microsegregation in CMSX-4 Superalloy and Its Homogenisation During Heat Treatment", Superalloys 2000, ed. T.M. Pollock, R.D. Kissinger (Warrendale, PA: TMS, 2000) 263-272. 